\title{
Exploring the Role of Resources in Ethnic Minorities' Adoption of Information and Communication Technology in Preserving Their Cultural Identity in Malaysia
}

\author{
Sarjit S. Gill ${ }^{1}$, A. T. Talib ${ }^{1}$, Choo Yeong Khong ${ }^{1} \&$ Puvaneswaran Kunasekaran ${ }^{1}$ \\ ${ }^{1}$ Faculty of Human Ecology, University Putra Malaysia \\ Correspondence: Sarjit S. Gill, Faculty of Human Ecology, University Putra Malaysia, 43400 Selangor, Malaysia. \\ Tel: 603-8946-7059.E-mail: sarjit@putra.upm.edu.my
}

Received: May 29, 2015 Accepted: June 8, 2015 Online Published: September 23, 2015

doi:10.5539/ach.v8n1p69 URL: http://dx.doi.org/10.5539/ach.v8n1p69

\begin{abstract}
The aim of this article is to investigate the current conditions of the adoption of Information and Communication Technology (ICT) in preserving cultural identity among the ethnic minorities in Peninsular Malaysia. ICT plays a crucial role in the present knowledge-based globalization era and the usage has become a basic necessity for all members of the society in managing their daily lives. It has pervaded every aspect of human life and has significantly changed the manner in which society communicate and interact with one another. This is particularly important as the ethnic minorities in Malaysia inevitably facing the great challenges of losing their cultural identity through the assimilation process into the larger mainstream society. ICT appear as an alternative which help in enhancing the efforts for cultural preservation. The penetration of ICT in ethnic minority everyday life has directly or indirectly provides a platform for them to express and share their ideas, thoughts, perceptions and knowledge about their existing culture. However, are the ethnic minorities have sufficient resources to adopt ICT to preserve their culture is still unexplored. The extent of the ethnic minorities' awareness of the advantages of ICT to preserve their cultural identity is still questionable.
\end{abstract}

Keywords: ICT, ethnic minorities, culture, resources, identity

\section{Introduction}

There is growing recognition of the importance of Information and Communication Technology (ICT) in human development, as its performance is of interest of all countries. Undeniably, ICT contributes greatly to the economic and social development of many countries such as increasing job opportunities, generating income and also speeding up development in urban and rural areas (Olutunla \& Obamuyi, 2008). In the era of globalization, ICT can be described as the backbone of all new technologies which is utilized for saving costs, improving efficiency and convenience, thus plays an important role in national development (Mugodi \& Flemming, 2003). Additionally, ICT also plays a key role in accelerating the process of economic growth by increasing the efficiency and productivity of all sectors of the economy (Malaysia, 2001). The revolutions in the use of ICT have profound implications on social development and have pervaded every aspect of human life (Shanker, 2008).

To become a developed nation by 2020, Malaysia has been seriously involved in ICT development. ICT is seen as a powerful technology in enhancing efficiency and effectiveness to improve the quality of life, thus improving and shaping the emerging generation (Gani \& Clemes, 2006; Kenny, 2002).In light of this, Malaysia has spent a great amount of money and resources for ICT development in order to enhance the ICT knowledge among the citizens. For instance, investments in ICT expanded at a rate of 9.2 per cent per annum from RM3.8 billion in 1995 to RM5.9 billion in 2000 in Seventh Malaysia Plan (Malaysia, 2001). During the Eighth Malaysia Plan, a total of RM5.2 billion was allocated for ICT-related programmes and projects (Malaysia, 2006). The determination to enhance ICT development can be seen clearly as the government is paying great attention to the efforts to increase the use of ICT among Malaysians in each Malaysia Plans. This can be seen through the establishment of the National Information Technology Agenda (NITA), accelerating the development of Multimedia Super Corridor (MSC) and the readiness to enhance ICT awareness among the people through ICT education and campaigns (Malaysia, 2001), as a strategic driver of economic growth and improve the quality of life for residents (Ishak \& 
Hassan, 2007).Through the establishment of the MSC, the ICT vision to drive Malaysia to become a competitive country in the era of globalization and information technology can be realized (Ting \& Woo, 2005).

Additionally, a number of initiatives have been taken such as the establishment of telecentres in rural and suburban areas throughout the country whereby many areas were connected through an initiative known as Kampung Wi-Fi (village without wires), using internet services via broadband and wireless technologies to increase household broadband penetration (Hazura et al., 2012), tariff revision of telephone and internet, and encourage computer ownership (Malaysia, 2006). Likewise, government has made some wise decisions which allow workers to withdraw money from Employees Provident Fund (EPF), provide flexible loan, and income tax exemption for computer purchase, to further promote the use of ICT among Malaysians (Hassan, 2008). In addition, another initiative taken was the implementation of Youth Communication Plan which aims to encourage the usage of mobile phone by providing rebate for the mobile phone purchase. Malaysia has implemented variety of infrastructure development to facilitate access to ICT to encourage and promote the use of ICT among citizens.

\subsection{ICT and Ethnic Minorities}

There are various ethnic minorities in Peninsular Malaysia such as the Siamese, Sikh, Baba Nyonya, Chitty, Portuguese and Orang Asli (indigenous people). The ethnic minorities account for only a small part of the total population in Peninsular Malaysia. This certainly disadvantaged them to be equally involved and benefits from the national development as other mainstream society in Malaysia. This is obviously seen as the minority communities seem alienated from mainstream socio-political structure in terms of the land development policy, political involvement and education participation (Juli Edo et al., 2013). Ethnic minorities has faced tremendous challenges under the stream of globalization and the marginalization process deteriorates the disparity among the ethnic minorities with the mainstream society. In light of this, the government should pay greater attention to the ethnic minorities through fair policies and consistent development efforts to develop the ethnic minorities. Hence, government should intensify the participation of ethnic minorities in the ICT development, especially with today's ICT strengths could improve the competitiveness of the ethnic minorities and enhance their cultural preservation. This could be seen as the ethnic minorities such as Orang Asli community in Malaysia increase their income by commercializing their culture (Kunasekaran et al., 2013).

\subsection{ICT and Culture}

Aggressive ICT development has always been labelled as an agent that eroded the ethnic cultural identity. This is in line with the arguments which indicated that the ethnic identity and cultures are facing crisis in this digital era with the rapid innovations in ICT which is said to be embedded with variety of foreign values (Dyson, 2004; Mustafa, 2006). ICT may be used to reinforce and accelerate the dominance of Western-based modes of thought, culture, and learning strategies which have resulted in massive and continuous exposure of the indigenous community to non-indigenous cultural values and information with few opportunities for reinforcement of their own cultural heritage and language (Resta, 2011). Thus, technology has often have unforeseen consequences to the minorities' culture. ICT might have huge impact on the ethnic minorities as they adopt the new technologies, loading unsuitable Western values onto them in a modern form of cultural imperialism.

Despite ICT always seen as a cultural erosion catalyst, however, some researchers argued that ICT could be very useful in maintaining ethnic identity and cultural preservation (Lieberman, 2003; Michael \& Dunn, 2006). This is particularly important as the ethnic minorities in Malaysia inevitably facing the challenges of losing their cultural identity through the assimilation process into the larger mainstream society. Therefore, how the ethnic minorities could sustain their cultural identity under the challenges being assimilated into the larger society in the stream of globalization remain questionable. Some scholars hold an optimistic view regarding the role of ICT in enhancing the cultural identity sustainability. For instance, Lieberman (2003) argued that although ICT causes inevitable clashes with local traditions, however, it can be used to preserve, promote, and strengthen the indigenous language and culture. This is in line with the argument by Michael and Dunn (2006) who indicated that the potential uses of ICT in key areas are fundamental to the continuing presence of the culture.

\section{Methodology}

This study adopted a quantitative approach to examine the role of resources in adoption of ICT in preserving cultural identity among the ethnic minorities in Peninsular Malaysia. The data were gathered by using survey questionnaire. The study involved 400 respondents consisted of six different ethnic minority groups namely Siamese, Sikh, Baba Nyonya, Chitty, Portuguese and Orang Asli, that aged 13 to 74 years old, were selected by using purposive sampling technique. The study was conducted in Selangor and Malacca states in Peninsular Malaysia. The data were analyzed by using Statistical Package for the Social Sciences (SPSS). 


\subsection{Instrumentation}

The questionnaire used in this study was developed based on the literature review to achieve the research objective. The questionnaire of the present study was designed to measure the resources possessed by the respondents and how it influences the use of ICT in preserving their cultural identity. The resources part consisted of six items with 5-point Likert scale ranged from $1=$ Strongly disagree to $5=$ Strongly agree. Higher score indicated higher possession of resources by the respondents. Meanwhile, the ICT use part consisted of nine items with 5-point Likert scale ranged from $1=$ ever to $5=$ Very often. Higher score indicated more frequent use of ICT in preserving culture by the respondents. In the present study, the Cronbach's alpha for resources and ICT use in preserving culture are .929 and .966 respectively.

\section{Results and Discussions}

Table 1. Demographic profiles of the respondents

\begin{tabular}{|c|c|c|}
\hline Variable & $\mathrm{n}$ & $\%$ \\
\hline \multicolumn{3}{|l|}{ Age (Years) } \\
\hline Less than 25 & 141 & 35.2 \\
\hline $25-35$ & 114 & 28.5 \\
\hline $36-45$ & 87 & 21.8 \\
\hline $46-55$ & 33 & 8.2 \\
\hline Above 55 & 25 & 6.2 \\
\hline \multicolumn{3}{|l|}{ Gender } \\
\hline Male & 185 & 46.2 \\
\hline Female & 215 & 53.8 \\
\hline \multicolumn{3}{|l|}{ Ethnic } \\
\hline Siam & 48 & 12.0 \\
\hline Sikh & 128 & 32.0 \\
\hline Baba Nyonya & 52 & 13.0 \\
\hline Chitty & 40 & 10.0 \\
\hline Portuguese & 40 & 10.0 \\
\hline Orang Asli (indigenous people) & 92 & 23.0 \\
\hline \multicolumn{3}{|l|}{ Religion } \\
\hline Islam & 1 & 0.2 \\
\hline Buddhism & 92 & 23.0 \\
\hline Hinduism & 39 & 9.8 \\
\hline Christianity & 48 & 12.0 \\
\hline Sikhism & 128 & 32.0 \\
\hline Animism & 91 & 22.8 \\
\hline Others & 1 & 0.2 \\
\hline \multicolumn{3}{|l|}{ Marital Status } \\
\hline Single & 196 & 49.0 \\
\hline Married & 204 & 51.0 \\
\hline \multicolumn{3}{|l|}{ Highest Education Qualification } \\
\hline No formal education & 14 & 3.5 \\
\hline Primary school & 102 & 25.5 \\
\hline Secondary school & 102 & 25.5 \\
\hline Certificate & 39 & 9.8 \\
\hline Diploma & 55 & 13.8 \\
\hline Bachelor degree & 82 & 20.5 \\
\hline Postgraduate & 6 & 1.5 \\
\hline \multicolumn{3}{|l|}{ Monthly Income (RM) } \\
\hline 0 & 146 & 36.5 \\
\hline$<500$ & 40 & 10.0 \\
\hline $500-1000$ & 45 & 11.2 \\
\hline $1001-2000$ & 44 & 11.0 \\
\hline $2001-4000$ & 73 & 18.2 \\
\hline $4001-7000$ & 40 & 10.0 \\
\hline$>7000$ & 12 & 3.0 \\
\hline
\end{tabular}


This section presents the empirical findings of the study. Table 1 presents the demographic profiles of the respondents. Majority of the respondents are female who aged below 25 years old and more than half of the respondents are married. Meanwhile, majority of the respondents have formal education until primary and secondary level. In terms of monthly income, the respondents who have zero monthly income are the highest proportion among all the respondents.

This study was conducted to examine the resources possessed by the respondents. Table 2 shows the mean and the standard deviation for each items of the resources variable.

Table 2. The mean result of the resources

\begin{tabular}{lcc}
\hline \multicolumn{1}{c}{ Items } & Mean & S.D. \\
\hline Financial resource is not a barrier for me to use ICT to preserve my culture. & 3.53 & 0.962 \\
I have access to the hardware and software I would need to use to preserve my culture. & 3.48 & 1.006 \\
I have the opportunity to use ICT because there is available network connection in my & 3.68 & 1.013 \\
residence. & & \\
I would be able to find the time to use ICT in preserving my culture. & 3.50 & 0.999 \\
If I needed someone's help in using ICT, I could get it easily. & 3.62 & 1.024 \\
I have sufficient ICT knowledge and skills to preserve my culture. & 3.54 & 0.993 \\
\hline
\end{tabular}

Note: 1 = Strongly disagree; 2 = Disagree; 3 = Neutral; 4 = Agree; 5 = Strongly agree.

Furthermore, respondents were asked to indicate how often they use ICT in preserving their culture. Table 3 shows the difference between the ethnic minorities groups of the ICT use in preserving their cultural identity. The findings indicated that the Siam community has the highest usage of ICT in preserving their cultural identity while the Orang Asli community has the lowest ICT usage to preserve their cultural identity. This is consistent with the argument that the Orang Asli community has always been the target for marginalization and exploitation are generally avoid contact with outsiders as a strategy of surviving. (Gomes, 2012).Meanwhile, Sarjit et al. (2009) indicated that ethnic minorities such as Orang Asli community are experiencing a digital divide not because of their values and beliefs instead due to insufficient knowledge, skills and infrastructure to facilitate their access in ICT.

Table 3. One-way ANOVA of ethnic groups with the level of ICT use in preserving culture

\begin{tabular}{rllcccccc}
\hline $\begin{array}{c}\text { Ethnic } \\
\text { (I) }\end{array}$ & Mean & Ethnic (J) & Mean & $\begin{array}{c}\text { Mean Difference } \\
\text { (I-J) }\end{array}$ & Std. Error & Sig. & F & Sig. \\
\hline Siam & 30.19 & Sikh & 26.95 & 3.234 & 1.502 & .262 & 18.236 & .000 \\
& & Baba & 23.19 & $6.995^{*}$ & 1.776 & .001 & & \\
& Nyonya & & & & & & \\
& Chitty & 26.18 & 4.012 & 1.899 & .283 & & \\
& Portuguese & 22.45 & $7.738^{*}$ & 1.899 & .001 & & \\
& Orang Asli & 17.48 & $12.709^{*}$ & 1.580 & .000 & & \\
\hline
\end{tabular}

Note: ${ }^{*} p<.05,{ }^{* *} p<.01,{ }^{* * *} p<.001 ; \mathrm{F}(5,394)=18.236, p<.000$.

Table 4. The correlation between resources and ICT use in preserving culture

\begin{tabular}{cccc}
\cline { 2 - 3 } & Variable & \multicolumn{2}{c}{ ICT use in preserving culture } \\
\cline { 2 - 3 } & \multicolumn{1}{c}{$\mathrm{r}$} & $\mathrm{p}$ \\
\hline & Resources & $.382^{* * *}$ & .000 \\
\hline
\end{tabular}

Note: $* * * p<.001$. 
The correlation between the resources and ICT use in preserving cultural identity was determined. The result was presented in Table 4. According to Table 4, the findings indicated that there is a significant positive relationship between the resources and ICT use in preserving culture $(\mathrm{r}=.382, \mathrm{p}=.000)$. The findings denoted that the resources availability plays an important role in determining the ICT use in preserving culture among the ethnic minorities. This is supported by Boyle and Wallace (2011) who asserted that adequate resources are fundamental element in influencing the ICT adoption by individual. Hence, it is obvious that individual adoption towards an innovation is greatly relies on the resources availability (Lin, 1998). Furthermore, the similar argument was raised by Mathieson and Chin (2001) who stated that adequate resources are important in determining the adoption of the technology to achieve a goal.

Apparently, resources play a significant role in influencing the adoption of ICT. Means and Olson (1997) indicated that insufficient access to resources such as equipment, time, training, support could be a barrier to ICT adoption. Ertmer (1999) highlighted that scarcity of resources in terms of training, technical support and time are obstacles to successfully adopt ICT. Lack of hardware, software, time, ICT knowledge and technical skills are barriers which inhibiting the use of ICT by individual (Jones, 2004; Goktas et al., 2009; Pelgrum, 2001).

As ethnic minorities in Malaysia are facing tremendous challenges of losing their cultural identity, ICT emerge as an alternative solution to preserve their culture. For instance, Michael and Dunn (2006) stated that the uses of ICT helps the Badimaya people of Western Australia to preserve their culture effectively from become extinct. Meanwhile, Chikonzo (2006) highlighted the importance of ICT in gathering, preserving and disseminating the indigenous knowledge in Africa. This is supported by Hunter (2005) who indicated that ICT plays a pivotal role for long term preservation of indigenous knowledge. Therefore, the ethnic minorities of Malaysia can adopt the same strategy and by so doing the invaluable culture could be preserved and pass to future generation.

\section{Conclusion}

ICT plays a vital role in the present digital era and it has become a basic need for all the society members in their daily lives. It has significantly changed the ways of communication and interaction among the society members. In this borderless globalization era, ICT certainly encourage the interconnectedness of social and cultural activities which causes inevitable clashes with local ethnic minorities traditions. Indeed, ICT has always been labelled as the cultural erosion catalyst. However, from a different point of view, ICT is merely a tool while humans itself is the final decider who can optimize the ICT usage in enhancing their cultural identity sustainability. Again, the findings of the present study showed that the resources availability plays an important role in determining the ethnic minorities' use of ICT in preserving their culture. At the same time, the present study revealed that more efforts need to be done in order to minimize the digital divide among the ethnic minorities with no ethnic being marginalized, in order to optimize the use of ICT among the ethnic minorities in preserving their culture and thus achieving a holistic sustainable development.

\section{Acknowledgements}

Deleted for double-blind review.

\section{References}

Boyle, A., \& Wallace, R. (2011). Indigenous people and e-nabling technologies: An analysis of recent experiences in northern and central Australia. Kulumun: Journal of the Wollotuka Institute, 1(1), 1-14.

Chikonzo, A. (2006). The potential of information and communication technologies in collecting, preserving and disseminating indigenous knowledge in Africa. The international information \& library review, 38(3), 132-138. http://dx.doi.org/10.1080/10572317.2006.10762714

Dyson, L. E. (2004). Cultural issues in the adoption of information and communication technologies by Indigenous Australians. Proceedings from cultural attitudes towards communication and technology, 58-71. Perth: Murdoch University.

Ertmer, P. (1999). Addressing first-and second-order barriers to change: Strategies for technology integration.Educational Technology Research and Development, 47(4), 47-61.

Gani, A., \& Clemes, M. D. (2006). Information and communications technology: a non-income influence on economic well being. International Journal of Social Economics, 33(9), 649-663. http://dx.doi.org/10.1108/ 03068290610683431

Goktas, Y., Yildirim, S., \& Yildirim, Z. (2009). Main barriers and possible enablers of ICTs integration into pre-service teacher education programs.Educational Technology and Society, 12(1), 193-204. 
Gomes, A. (2012). Alter-Native 'Development': indigenous forms of social ecology. Third World Quarterly, 33(6), 1059-1073. http://dx.doi.org/10.1080/01436597.2012.681491

Hassan, M. A. (2008). Inaugural Lecture Series: Memanfaatkan Teknologi Maklumat dan Komunikasi untuk Semua. Serdang: Universiti Putra Malaysia.

Hazura, M., Hairulliza, M. J., Siti, F. M. N., \& Zawiyah, M. Y. (2012). Bridging digital divide: A study on ICT literacy among students in Malaysia rural areas. Australia Journal of Basic and Applied Sciences, 6(7), $39-40$.

Hunter, J. (2005). The role of information technologies in indigenous knowledge management. Australian Academic \& Research Libraries, 36(2), 109-124. http://dx.doi.org/10.1080/00048623.2005.10721252

Ishak, M. S., \& Hassan, M. A. (2007).Keengganan memiliki komputer dan Internet di rumah: Satu persoalan jurang digital dalam kalangan masyarakat Malaysia. Kertas seminar International Conference on Media and Communication Sekolah Pengajian Media \& Komunikasi, Fakulti Sains Sosial \& Kemanusiaan, Universiti Kebangsaan Malaysia.

Jones, A. (2004). A review of the research literature on barriers to the uptake of ICT by teachers.British Educational Communications and technology Agency, 1-29.

Juli Edo, Siti Nor, A., Fadzil, K. S., Zainol, R., \& Wan Suzita, W. I. (2013). Pendidikan dan hak asasi kanak-kanak: Satu tinjauan cabaran dan hala tuju pendidikan awal kanak-kanak Orang Asli di Kompleks Belum-Temenggor. Man and Society, 23, 1-18.

Kenny, C. (2002). Information and communication technologies for direct poverty alleviation: Cost and benefits. Development Policy Review, 20(2), 141-157.

Kunasekaran, P., Gill, S. S., Talib, A. T., \& Redzuan, M. R. (2013). Culture As An Indigenous Tourism Product Of Mah Meri Community In Malaysia. Life Science Journal, 10(3), 1600-1604.

Lieberman, A. E. (2003). Taking ownership: Strengthening indigenous cultures and languages through the use of ICTs. Retrieved on March 20, 2015 from http://www.guidestarinternational.org/documents/ Takingownership-Strengthening Indigenous Cultures and Languages through the Use ICTs.pdf

Lin, C. A. (1998). Exploring personal computer adoption dynamics.Journal of Broadcasting \& Electronic Media, 42(1), 95-112. http://dx.doi.org/10.1080/08838159809364436

Malaysia. (2001). Eighth Malaysia Plan, 2001-2005. Putrajaya: Economic Planning UnitPrime Minister's Department Malaysia. Retrieved on March 15, 2015, from http://www.epu.gov.my/en/eighth-malaysia -plan-2001-2005

Malaysia. (2006). Ninth Malaysia Plan, 2006-2010. Putrajaya: Economic Planning Unit Prime Minister's Department Malaysia. Retrieved on March 15, 2013, from http://www.epu.gov.my/en/ninth-malaysia-plan $-2006-2010$

Mathieson, K., \& Chin, W. W. (2001).Extending the technology acceptance model: The influence of perceived user resources.Database for Advances in Information Systems, 32(3), 86-112.

Means, B., \& Olson, K. (1997). Technology and education reform: Studies of education reform. Diane Publishing.

Michael, K., \& Dunn, L. (2006). The use of information and communication technology for the preservation of aboriginal culture: The Badimaya people of Western Australia. In L. Dyson (Eds.), Information Technology and Indigenous People. Australia: Idea Group Publishing.

Mugodi, T. Z., \& Fleming, D. R. (2003). A study of ICT diffusion into South Africa's platinum mining sector. Application of Computers and Operations Research in the Minerals Industries, 505-510.

Mustafa, K. O. C. (2006). Cultural identity crisis in the age of globalization and technology.The Turkish Online Journal of Educational Technology, 5(1), 37-43.

Olutunla, G. T., \& Obamuyi, T. M. (2008). An empirical analysis of factors associated with the profitability of small and medium enterprises in Nigeria. African Journal of Business Management, 2(x), 195-200.

Pelgrum, W. J. (2001). Obstacles to the integration of ICT in education: Results from a worldwide educational assessment. Computers and Education, 37, 163-178.

Resta, P. (2011). ICTs and Indigenous People. Moscow: UNESCO Institute for Information Technologies in Education. 
Sarjit S. G., Amir Zal, W. A., \& Ma'rof, R. (2009). Jurang digital belia Orang Asli di Bukit Lanjan. Malaysian Journal of Youth Study, 1(1), 69-97.

Shanker, D. (2008). ICT and Tourism: challenges and opportunities. Paper presented at the Conference on Tourism in India-Challenges Ahead, 15, 17.

Ting, K. S., \& Woo, Y. L. (2005). Penggunaan ICT dalam Proses Pengajaran dan Pembelajaran dalam kalangan Guru Sekolah Menengah Teknik dan Vokasional: Sikap Guru, Peranan ICT dan Kekangan / Cabaran Penggunaan ICT. Kertas Kerja Seminar Pendidikan 2005, Fakulti Pendidikan Universiti Teknologi Malaysia.

\section{Copyrights}

Copyright for this article is retained by the author(s), with first publication rights granted to the journal.

This is an open-access article distributed under the terms and conditions of the Creative Commons Attribution license (http://creativecommons.org/licenses/by/3.0/). 